Postgraduate Bosowa University Publishing (PBUP)
Indonesian Journal of Business and Management
e-ISSN: $2460-3767 \quad p$-ISSN: $2656-6885$
Pttps://postgraduate.universitasbosowa.ac.id/index.php/jbm

\title{
PENGARUH PELATIHAN DAN KOMPETENSI INSTRUKTUR TERHADAP KINERJA PEGAWAI BALAI LATIHAN KERJA KABUPATEN PANGKEP
}

\section{The Influence of Instructor Training And Competence on Employee Performance at The Pangkep Regency Job Training Center Kabupaten Pangkep}

\author{
Syahruddin $^{1}$, Hasanuddin Remmang ${ }^{2}$, Seri Suriani ${ }^{2}$ \\ ${ }^{1}$ Balai Latihan Kerja Kabupaten Pangkep \\ ${ }^{2}$ Program Studi Manajemen Program Pascasarjana Universitas Bosowa
}

Email: undingsahabat@gmail.com

Diterima: 20 September 2021/Disetujui: 24 Desember 2021

\begin{abstract}
ABSTRAK
Penelitian ini untuk mengetahui hubungan antara pengaruh pelatihan dan kompetensi instruktur terhadap kinerja pegawai balai latihan kerja kabupaten pangkep. Analisis yang digunakan adalah analisis regresi linear berganda dengan model uji $\mathrm{t}$ dan uji F. Dari hasil pengujian regresi linear berganda diketahui bahwa pelatihan dan kompetensi berpengaruh positif dan signifikan terhadap kinerja pegawai. Indikator Kebutuhan pelatihan, Sasaran pelatihan, Kurikulum pelatihan, Peserta pelatihan, dan Pelatih (trainer), mempengaruhi kinerja pegawai telah menjadi bukti empirik sebagai syarat peningkatkan kinerja pegawai.. Pengeloaan data regresi berganda yang dilakukan dalam penelitian ini memberikan hasil bahwa pelatihan, kompetensi instruktur berpengaruh positif dan signifikan terhadap kinerja pegawai pada Balai Latihan Krja Kabupaten Pangkep. Hal ini dapat dilihat dari nilai probabilitas yang lebih kecil dari nilai standar. Nilai F hitung yang lebih besar dari nilai $\mathrm{F}$ tabel menjadi tolak ukur hasil dari penelitian ini tentang pengaruh setiap variable.
\end{abstract}

Kata Kunci: Pelatihan, Kompetensi Kerja, Kinerja Pegawai

\section{ABSTRACT}

This study was to determine the relationship between training and competence on the performance of the Pangkep district job training center employees. The analysis used is multiple linear regression analysis with t test and $F$ test models. It is known from the results of multiple linear regression testing that training and competence have a positive and significant effect on employee performance. Indicators of training needs, training targets, training curriculum, training, and trainers, affect employee performance as a condition for improving employee performance. positive and significant impact on employee performance at the Pangkep Regency Job Training Center. This can be seen from the probability value which is smaller than the standard. The calculated $F$ value which is greater than the F table value becomes the benchmark for the results of this study regarding the effect of each variable.

Keywords: Training, Work Competence, Employee Performance

This work is licensed under Creative Commons Attribution License 4.0 CC-BY International license

\section{PENDAHULUAN}

Salah satu masalah makro ekonomi adalah pengangguran. Pengangguran terjadi disebabkan oleh lapangan pekerjaan yang tidak tersedia atau tidak mencukupi serta ketersediaan tenaga kerja pada pasar tenaga kerja. Ketersediaan tenaga kerja tidak berarti bahwa tidak adanya manusia yang ingin bekerja, akan tetapi kebutuhan tenaga kerja dan tenaga kerja yang tersedia tidak mengalami kesesuaian. Sumber Daya Manusia menjadi kebutuhan dalam segala aspek kehidupan, terutama dalam dunia bisnis maupun instansi pemerintahan. Kebutuhan Sumber Daya Manusia sangat tinggi, terutama dalam era modern sekarang ini.

Pelatihan ada hal penting dlaksanakan agar pegawai memiliki pengalaman dan keterampilan, Tyson (2014) menyatakan bahwa pelatihan bertujuan untuk mencapai tujuan jangka pendek organisasi sedangkan pendidikan 
diarahkan pada pembangunan pegawai jangka panjang. Biech (2014) menyatakan bahwa pelatihan adalah tentang perubahan, tentang transformasi, tentang pembelajaran. Pelatihan adalah proses yang dirancang untuk membantu pegawai mempelajari keterampilan, pengetahuan, atau sikap barn. Akibatnya, pegawai tersebut akan membuat perubahan atau transformasi yang akan meningkatkan kineljanya. Perbaikan ini memastikan bahwa pegawai dan organisasi mampu melakukan hal-hal yang lebih baik, lebih cepat, lebih mudah, dengan kualitas yang lebih tinggi dan laba atas investasi yang lebih baik. Sebagai sumber daya manusia dalam suatu organisasi dibutuhkan kompetensi agar pekerjaan yang dihadapi dapat dilaksanakan dengan baik. Kompetensi adalah suatu kemampuan yang dimiliki oleh seorang individu yang memiliki nilai jual dan itu teraplikasi dari hasil kreativitas serta inovasi yang dihasilkan. Sebagai penguat pemikiran kita maka pendapat dari Boulder juga perlu kita sirnak. Kompetensi adalah karakteristik dasar dari seseorang yang memungkinkan mereka mengeluarkan kinerja superior dalam pekerjaannya, Boulder et. al, 92014). Adapun pengertian kompetensi kerja menurut Undangundang Republik Indonesia Nomor 13 Tahun 2003 tentang Ketenagakerjaan Bab I Pasal 10 yang berbunyi, "Kompetensi kerja adalah kemampuan kerja setiap individu yang mencakup aspek pengetahuan, keterampilan, dan sikap kerja yang sesuai dengan standard yang ditetapkan."

Penilaian pekerjaan adalah suatu metode untuk membandingkan berbagai pekerjaan dengan menggunakan prosedur-prosedur formal dan sistematis untuk menentukan urutan pekerjaan-pekerjaan melalui penentuan kedudukan dan rasio antara satu pekerjaan dengan yang lainnya. Hasil dari penilaian ini disebut sebagai kinerja, yang dapat dijadikan sebagai dasar untuk memberikan suatu sistem upah yang adil. Keberhasilan penentuan pencapaian tugas terhadap individu akan dapat mengarahkan penetapan kinerja organisasi. Menurut Kusriyanto dalam Pasolong, (2015), kinerja adalah hasil kerja perseorangan dalam suatu organisasi. Sedangkan menurut Nurhayati (2015), kinerja adalah tingkat dimana para karyawan mencapai persyaratan-persyaratan pekerjaan. Nawawi (2016), kinerja dikatakan tinggi apabila suatu target kerja dapat diselesaikan pada waktu yang tepat atau tidak melampaui batas waktu yang disediakan. Terdapat dua aspek penting yang perlu diperhatikan dalam mencapai kinerja kelompok, yaitu hubungan antara keterpaduan dengan kinerja kelompokdan perbedaan-perbedaan antara pemecahan masalah dengan pengambilan kepuumn secara individu dan kelompok. Oleh sebab itu, keberhasilan atau kegagalan pegawai dalam memenuhi tujuan-tujuan organisasi ditentukan oleh kemampuan mereka dalam memimpin kelompok secara terpadu. Dalam suatu organisasi atau masyarakat, para individu menyumbangkan kinerjanya kepada kelompok. selanjutnya kelompok akan menyumbangkan kinerjanya kepada organisasi atau masyarakat. Dalam organisasi yang efektif, manajemen selalu mendptakan sinergi positif, yang menghasilkan satu keseluruhan menjadi lebih besar dari jumlah seluruh komponen bagiannya. Seiring dengan pendapat tersebut, Withmore mengemukakan kinerja merupakan ekspresi potensi seseorang dalam memenuhi tanggung jawabnya dengan menetapkan standar tertentu.

Sehubungan dengan usaha meningkatkan kualitas sumber daya manusia dalam menghadapi ketatnya persaingan dalam dunia kerja, maka terbentuklah Balai Latihan Kerja Industri (BLKI) yang didirikan atas kerja sama antara pemerintah republik Indonesia dan pemerintahan jepang yang masingmasing diwakili oleh Departemen Tenaga Kerja Transmigrasi dan Koperasi Republik Indonesia dan Japan International Cooperation Egency (JICA) pada tahun 1973. Kemudian BLKI dibentuk di setiap kabupaten kota termasuk pada kabupaten Pangkajene dan Kepulauan Provinsi Sulawesi Selatan. BLKI Kabupaten Pangkep menjadi salah satu unit pelaksana teknis pusat (UPTP) berdasarkan SK Mennakertrans No. Per.06/MEN/III/2006 tanggal 15 maret 2006, secara operational administratif bertanggung jawab langsung kepada Dirjen Pembinaan Pelatihan dan Produktivitas dan secara operational teknis dibawah Direktorat Instruktur dan Tenaga Pelatihan (INTALA).

Berkaitan dengan itu tentunya diharapkan BLKI mampu memberikan kinerja yang baik agar menghasilkan Sumber Daya Manusia yang siap dan berkualitas. Tenaga kerja yang disiapkan menjadi jawaban dari masalah Makro Ekonomi yaitu penekanan tingkat pengangguran. Menurunnya tingkat pengangguran tentunya berbanding lurus dengan kesiapan tenaga kerja pada pasar tenaga kerja. Sumber Daya Manusia yang berkualitas akan di hasilkan dari system pembentukan yang baik. Pemberian pelatihan yang dibutuhkan serta tenaga pelatih (instruktur) hendaknya mempunya kualifikasi yang baik. Tujuanl penelitian ini untuk mengetahui pengaruh pelatihan dan kompetensi instruktur terhadap kinerja pegawai balai latihan kerja Kabupaten Pangkep.

\section{METODE}

\section{a. Jenis Penelitian}

Penelitian dengan judul "Pengaruh Pelatihan dan Kompoten Instruktur Terhadap Kinerja Pegawai Pada Badan Pelatihan Kerja (BLK) Daerah Kabupaten Pangkep", berbentuk teknik analisis deskriptif kuantitatif yang menyajikan hasil penelitian dalam bentuk angkaangka dengan menggunakan metode analisis regresi linear berganda.

\section{b. Populasi dan Sampel}

Populasi adalah sekelompok orang, kejadian atau segala sesuatu yang mempunyai karakteristik tertentu, sedangkan sampel adalah bagian dari populasi yang diambil melaui cara-cara tertentu yang juga memiliki karakteristik tertentu, jelas dan lengkap yang dianggap bisa mewakili populasi. 
Penelitian yang menggunakan metode survey, tidak harus meneliti seluruh individu dalam populasi yang ada, karena akan membutuhkan biaya yang besar dan juga waktu yang lama. Penelitian dapat dilakukan dengan meneliti sebagian dari populasi (sampel), diharapkan hasil yang diperoleh dapat mewakili sifat atau karakteristik populasi yang bersangkutan.Populasi yang dimaksud disini adalah peserta pelatihan pada Balai Latihan Kerja (BLK) Daerah Kabupaten Pangkep.

Dalam menetapkan besarnya sampel (sampel size) dalam penelitian ini menggunakan sampel non probability yaitu sampel jenuh, dimana semua populasi dijadikan sampel. Biasanya hal ini terjadi karena jumlah populasi sedikit.

\section{c. Variabel Penelitian}

Pada penelitian ini terdapat tiga macam variabel, yaitu variabel terikat (variabel dependen) merupakan variabel yang tergantung dengan variabel yang lainnya dan variabel bebas (variabel independen) merupakan variabel yang tidak memiliki ketergantungan terhadap variabel yang lainnya. serta variabel mediasi. Variabel yang digunakan dalam penelitian ini antara lain:

1) Variabel Independen (X)

Variabel independen atau variabel bebas merupakan variabel yang mempengaruhi atau menjadi sebab perubahan atau timbulnya variabel dependen (terikat). Variabel independen dalam penelitian ini adalah Pelatihan (X1) Kompetensi (X2)

2) Variabel Dependen (Y)

Variabel dependen atau variabel terikat merupakan variabel yang dipengaruhi atau yang menjadi akibat karena adanya variabel bebas. Variabel dependen dalam penelitian ini adalah Kinerja (Y)

\section{d. Jenis dan Sumber Data}

Dalam penelitian ini menggunakan data sebagai alat hitung, jenis data yang digunakan adalah:

1) Data kuantitatif, adalah data yang berupa bilangan, nilainya bias berubah-ubah atau bersifat variatif.

2) Data kualitatif, adalah data yang bukan merupakan bilangan, tetapi berupa ciri-ciri, sifa-sifat, keadaan,atau gambaran dari kualitas objek yang diteliti.

Berdasarkan sumbernya, data yang dikumpulkan penulis dapat dibedakan dalam dua hal, yaitu:

1) Data Primer

Data diperoleh secara langsung dari instansi yang diteliti, melalui pengamatan dan pembagian kuesioner. Data yang dikumpulkan bersifat kualitatif berupa data mengenai hal-hal yang berhubungan dengan judul penelitan yang dipilih. Dalam penelitian ini data primer dengan menyebar kuesioner kepada peserta pelatihan saat penelitian ini dilaksanakan pada Balai Pelatihan Kerja (BLK) Daerah Kabupaten Pangkep.

2) Data sekunder Data yang dikumpulkan oleh penulis dari dokumendokumen yang ada di perusahaan tersebut, dari hasil penelitian kepustakaan, dan dari instansi atau perusahaan lainnya yang terkait. Data ini berupa gambaran umum perusahaan, misalnya sejarah berdirinya, struktur organisasi, uraian tugas dan tanggungjawab.

\section{e. Teknik Pengumpulan Data}

Metode pengumpulan daya yang digunakan dalam penelitian ini adalah sebagai berikut:

1) Koesioner

Metode pengumpulan data ini dengan cara menyusun daftar pertanyaan pada butir-butir variable yang diteliti, dimana muatan pertanyaan sesuai dengan indikator-indikator penilaian pada variable tersebut.

2) Dokumentasi

Metode pengumpulan data ini yaitu dengan mengumpulakan data-data yang dibutuhkan berasal dari laporan perusahaan sebagai dokumen perusahaan.

\section{f. Teknis Analisis Data}

Berdasarkan permasalahan dan hipotesis yang telah dikemukakan sebelumnya, dalam menguji kebenarannya maka digunakan teknik analisis data yaitu sebagai berikut:

1) Analisis kualitatif adalah suatu analisis yang memberikan gambaran atau menguraikan mengenai jawaban-jawaban responden atas item-item yang terdapat dalam kuesioner dan akan diolah dengan cara dikelompokkan dan ditabulasikan kemudian diberi penjelasan.

2) Analisis Regresi Berganda yaitu suatu analisis untuk melihat seberapa besar pengaruh Etika Profesi, Kompetensi dan Kerjasama Tim terhadap Kualitas Laporan hasil Pengawasan degan persamaan yaitu :

$\mathrm{Y}=\mathrm{a}+\beta 1 \mathrm{X} 1+\beta 2 \mathrm{X} 2+\beta 3 \mathrm{X} 3+\mathrm{e}$.

Dimana :

$\mathrm{Y}=$ Kualitas Laporan Hasil Pengawasan

$\mathrm{X}_{1}=$ Etika Profesi

$\mathrm{X}_{2}=$ Kompetensi

$\mathrm{X}_{3}=$ Kerjasama Tim

$\beta_{\mathrm{o}}=$ Konstanta

$\mathrm{e} \quad=$ Tingkat kesalahan

3) Uji Validitas dan Reliabilitas

Pengembangan instrument ditempuh melalui beberapa cara, yaitu selain mendefinisikan operasional variabel penelitian, menyusun indikator variabel penelitian dan melakukan uji coba instrument, dalam penelitian harus melakukan pengujian validitas dan reliabilitas.

a. Uji Validitas

Untuk menguji apakah instrumen yang dipakai cukup layak digunakan sehingga mampu menghasilkan data yang akurat sesuai petunjuk pengukurannya maka dilakukan uji validitas. Menurut Sugiyono (2010, hal 172), "Valid artinya data-data yang diperoleh dengan penggunaan alat (instrumen) dapat menjawab tujuan penelitian"

b. Uji Reliabilitas

Menurut Situmorang dan Lufti (2011, hal 79). "Reliabilitas adalah indeks yang menunjukkan 
sejauh mana suatu alat pengukur dapat dipercaya atau dapat didandalkan". Butir pertanyaan yang sudah dinyatakan valid dalam ujian validitas ditentukan reliabilitasnya dengan kriteria sebagai berikut:

1) Jika positif atau lebih besar dari a maka pertanyaan reliable

2) Jika negatif atau lebih kecil dari a maka pertanyaan tidak reliabel.

Jika nilai koefisien alpha lebih besar dari 0,6 maka disimpulkan bahwa instrument penelitan tersebut handal atau reliable.

4. Uji Asumsi klasik

Uji asumsi klasik bertujuan untuk menguji apakah model regresi linear bebas dari adanya bias atau penyimpangan sehingga diperoleh regresi yang benar BLUE (Best Linier Unbiased Estimation), yang terdiri dari:

\section{a. Uji Multikolineritas}

Hasil uji multikolineritas menunjukkan besarnya nilai tolerance untuk semua variabel $>$ 0,1 dan nilai VIF masing-masing variabel $<10$ maka tidak terjadi multikolineritas.

b. Uji Heterokesdastisitas

Pengujian heterokesdastisitas dalam penelitian ini dilakukan dengan Glejser Test dengan pvalue masing-masing > 0,05, maka model regresi tidak terjadi heterokesdastisitas.

c. Uji Normalitas

Pengujian normalitas dapat dilakukan dengan uji kosmogorov-smirnov test, hasil pengujian menunjukkan bahwa apabila pvalue atau signifikan > nilai standar, maka data residual berdistribusi normal.

5. Uji Hipotesis

a. $\quad$ Uji T (Uji parsial)

Uji ini adalah untuk mengetahui apakah pengaruh masing-masing variabel bebas terhadap variabel terikat bermakna atau tidak, pengujian ini dilakukan dengan membandingkan antara nilai $\mathrm{t}_{\text {hitung }}$ masingmasing variabel bebas dengan nilai $t_{\text {tabel }}$ dengan derajat kesalahan 5\% $(\alpha=0.05)$. Apabila nilai $t_{\text {hitung }} \geq t_{\text {tabel }}$, maka variabel bebasnya memberikan pengaruh bermakna terhadap variabel terikat.

b. Uji F (Uji Simultan)

Uji ini digunakan untuk mengetahui apakah seluruh variabel bebasnya secara bersama-sama mempunyai pengaruh yang bermakna terhadap variabel terikat. Pengujian dilakukan dengan membandingkan nilai $\mathrm{F}_{\text {hitung }}$ dengan $\mathrm{F}_{\text {tabel }}$ pada derajat kesalahan $5 \%(\alpha=0.05)$. Apabila nilai $F_{\text {hitung }} \geq$ dari nilai $F_{\text {tabel }}$, maka berarti variabel bebasnya secara bersama-sama memberikan pengaruh yang bermakna terhadap variabel terikat. Dengan menggunakan alat bantu program SPSS versi 26.

6. Koefisien Determinasi $\left(\mathrm{R}^{2}\right)$

Koefisien determinasi $\left(\mathrm{R}^{2}\right)$ dimaksudkan untuk mengetahui tingkat ketepatan paling baik dalam analisa regresi dimana hal yang ditunjukan oleh besarnya koefisien determinasi $\left(\mathrm{R}^{2}\right)$ antara 0 (nol) dan I (satu). Koefsien determinasi $\left(\mathrm{R}^{2}\right)$ nol variabel independen sama sekali tidak berpengaruh terhadap variabel dependen. Apabila koefisien determinasi semakin mendekati satu, maka dapat dikatakan bahwa variabel independen berpengaruh terhadap variabel dependen

\section{HASIL DAN PEMBAHASAN}

\section{1) Karakteristik Responden Penelitian}

Responden dalam penelitian ini adalah Pegawai dalam Lingkup Badan Latihan Kerja Kabupaten Pangkep. Lingkup Badan Latihan Kerja Kabupaten Pangkep meliputi pegawai BLK Kabupaten Pangkep. Responden sebanyak 60 orang yang penulis temui pada saat penelitian berlangsung.

Karakteristik responden yang diteliti dalam penelitian ini meliputi jenis kelamin responden, umur responden dan tingkat pendidikan responden. Pengetahuan mengenai karakteristik responden sangat perlu sebagai barometer penguatan hasil penelitian secara realistis.

\section{a) Jenis Kelamin}

Hasil penelitian ini menunjukkan Obahwa dari 60 orang responden yang diambil sebagai sampel, terdiri dari laki-laki dan perempuan dengan proporsi seperti tampak pada table di bawah ini :

Tabel 1. Karakteristik Responden Berdasarkan Jenis Kelamin

\begin{tabular}{lcc}
\hline Jenis Kelamin & Frekuensi & Persentase (\%) \\
\hline Perempuan & 37 & 61.66 \\
Laki-Laki & 27 & 38.34 \\
\hline Jumlah & 60 & 100 \\
\hline
\end{tabular}

Sumber : Data Diolah 2021

Berdasarkan tabel tersebut yaitu deskripsi identitas responden berdasarkan jenis kelamin, menunjukkan bahwa responden yang berjenis kelamin perempuan sebanyak 37 orang $(61,66 \%)$. Dan yang berjenis kelamin laki-laki sebanyak 23 orang $(38,34 \%)$.

Faktor jenis kelamin seseorang dapat mempengaruhi kinerja pegawai. Produktifitas kerja seseorang dapat pula dipengaruhi oleh faktor jenis kelamin. Umumnya laki-laki mampu bekerja lebih produktif dibandingkan dengan perempuan, hal ini dipengaruhi oleh kondisi fisik yang sangat berbeda antara Laki-laki dengan perempuan. 


\section{b) Usia}

Usia merupakan salah satu faktor yang mempengaruhi kemampuan kerja dan kinerja. Seseorang akan mengalami peningkatan kemampuan kerja seiring dengan meningkatnya usia, akan tetapi selanjutnya akan mengalami penurunan kamampuan kerja pada titik umur tertentu. Berdasarkan hal tersebut maka dikenal adanya umur produktif dan umur nonproduktif. Umur produktif adalah umur dimana seseorang memiliki kemampaun untuk menghasilkan produk maupun jasa. Usia produktif 20 - 45 tahun masih memiliki semangat yang tinggi dan mudah mengadopsi hal-hal baru. Berbeda dengan pekerja yang telah berusia lanjut (di atas 50 tahun). Mereka yang berusia lanjut cenderung fanatik terhadap tradisi dan sulit untuk diberikan pengertian-pengertian yang dapat mengubah cara berfikir, cara kerja dan cara hidupnya. Berikut disajikan jenis responden berdasarkan tingkat umur pada kantor Balai Latihan Kerja Kabupaten Pangkep :

Tabel 2. Karakteristik Responden Berdasarkan Usia

\begin{tabular}{ccc}
\hline Usia (tahun) & $\begin{array}{c}\text { Jumlah Responden } \\
\text { (orang) }\end{array}$ & Persentase (\%) \\
\hline $20-30$ & 20 & 33.33 \\
$31-40$ & 27 & 45.00 \\
$41-50$ & 11 & 18.33 \\
$>50$ & 2 & 3.33 \\
\hline Jumlah & 60 & 100 \\
\hline
\end{tabular}

Sumber : Data Diolah 2021

Dari tabel tersebut dapat lihat bahwa kebanyakan responden berusia 31-40 tahun yaitu 27 orang dengan persentase sebesar $45.00 \%$. Selanjutnya responden dengan usia 20-30 tahun sebanyak 20 orang dengan persentase sebesar 33.33\%. Pada usia 41-50 tahun jumlah responden sebanyak 11 orang dengan persentase sebesar $18.33 \%$, dan untuk usia diatas 50 tahun sebanyak 2 orang dengan persentase sebesar $3.33 \%$.

\section{c) Pendidikan}

Semakin tinggi tingkat pendidikan pegawai maka akan semakin tinggi kualitas sumberdaya manusia, yang pada gilirannya akan semakin tinggi pula kinerja yang dilakukannya. Oleh karena itu, dengan semakin tingginya pendidikan pegawai maka diharapkan kinerja pegawai dapat sampai hasil yang di inginkan. Dari pernyataan tersebut menunjukkan bahwa tingkat pendidikan merupakan salah satu faktor yang mempengaruhi seseorang dalam pekerjaan yang digelutinya. Seseorang yang mempunyai tingkat pendidikan yang tinggi dapat melaksakan kerjanya dengan baik karena ditunjang dengan ilmu pengetahuan secara konsep yang akan menunjang pengalaman kerjanya. Berikut disajikan jenis responden berdasarkan tingkat pendidikan pada kecamatan Pangkajene.
Tabel 3 Karakteristik Responden Berdasarkan Tingkat Pendidikan

\begin{tabular}{lcc}
\hline T. Pendidikan & Frekuensi (orang) & Persentase (\%) \\
\hline SMA & 10 & 16.67 \\
Diploma & 16 & 26.67 \\
Sarjana & 21 & 35.00 \\
Pascasarjana & 13 & 21.67 \\
\hline Jumlah & 60 & 100
\end{tabular}

Dari tersebut menunjukkan bahwa pada umumnya responden memiliki tingkat pendidikan sarjana, dimana terdapat sebanyak 21 responden atau $35.00 \%$ dari 60 responden. Sedangkan yang memiliki tingkat pendidikan terendah yaitu SMA sebanyak 10 orang atau sebesar $16.67 \%$. Tingkat pendidikan diploma sebanyak 16 orang atau $27.67 \%$, dan untuk tingkat pendidikan pascasarjana sebanyak 13 orang atau $21.67 \%$.

\section{2) Deskripsi Variable}

Pada dasarnya penelitian ini bertujuan untuk menganalisis pengaruh pelatihan dan kompetensi instruktur terhadap kinerja pegawai Balai Latihan Kerja Kabupaten Pangkep. Penelitian ini menggunakan dua variabel independen yaitu Pelatihan (X1), Kompetensi (X2), dan Kinerja Pegawai (Y). Penelitian ini dilakukan dengan menggunakan data primer, yaitu data yang diperoleh langsung dari kantor Balai Latihan Kerja Kabupaten Pangkep dan Data Sekunder yang diperoleh dari hasil hitungan program SPSS Versi 25 For Windows melalui hasil jawaban pegawai yang diberikan memalui koesioner.

\section{a) Variabel Pelatihan}

Pelatihan adalah sebuah upaya yang sistematis dan terencana untuk mengubah atau mengembangkan pengetahuan, keterampilan, sikap baru yang sesuai dengan kebutuhan organisasi. Pelatihan memungkinkan pegawai memperoleh kemampuan tambahan sehingga ia dapat mengemban tugas atau pekerjaan aktual yang dihadapi secara lebih baik, lebih cepat. lebih mudah, dengan kualitas pekerjaan yang lebih tinggi dan menghasilkan kinerja dan produktivitas kerja yang lebih baik.

Deskripsi terhadap variable pelatihan dilakukan dari hasil jawaban responden mengenai pertanyaan indikatorindikator pelatihan dengan nilai rata-rata sebagai berikut: Tabel 4.Tanggapan Responden atas Variabel Pelatihan

\begin{tabular}{|c|c|c|c|c|c|c|}
\hline \multirow{2}{*}{ Pertanyaan } & \multicolumn{5}{|c|}{ Jawaban } & \multirow{2}{*}{ Frekuens } \\
\hline & STS (5) & TS (4) & $\mathrm{N}(3)$ & S (2) & SS (1) & \\
\hline 1 & 2 & 4 & 8 & 33 & 13 & 60 \\
\hline & $3.33 \%$ & $(6.67 \%)$ & $(13.33 \%)$ & $(55.00 \%)$ & $(21.67 \%)$ & $(100 \%)$ \\
\hline 2 & $\begin{array}{c}3 \\
(5.00 \%)\end{array}$ & $\begin{array}{c}6 \\
(10.00 \%)\end{array}$ & $\begin{array}{c}7 \\
(11.67 \%)\end{array}$ & $\begin{array}{c}31 \\
(51.67 \%)\end{array}$ & $\begin{array}{c}13 \\
(21.67 \%)\end{array}$ & $\begin{array}{c}60 \\
(100 \%)\end{array}$ \\
\hline 3 & $\begin{array}{c}2 \\
(3.33 \%)\end{array}$ & $\begin{array}{c}5 \\
(8.33 \%)\end{array}$ & $\begin{array}{c}6 \\
(10.00 \%)\end{array}$ & $\begin{array}{c}32 \\
(53.33 \%)\end{array}$ & $\begin{array}{c}15 \\
(25.00 \%)\end{array}$ & $\begin{array}{c}60 \\
(100 \%)\end{array}$ \\
\hline 4 & $\begin{array}{c}1 \\
(1.67 \%)\end{array}$ & $\begin{array}{c}5 \\
(8.33 \%)\end{array}$ & $\begin{array}{c}9 \\
(15.00 \%)\end{array}$ & $\begin{array}{c}33 \\
(55.00 \%)\end{array}$ & $\begin{array}{c}12 \\
(20.00 \%)\end{array}$ & $\begin{array}{c}60 \\
(100 \%)\end{array}$ \\
\hline 5 & $\begin{array}{c}2 \\
(3.33 \%)\end{array}$ & $\begin{array}{c}4 \\
(6.67 \%)\end{array}$ & $\begin{array}{c}10 \\
(16.67 \%)\end{array}$ & $\begin{array}{c}28 \\
(46.67 \%)\end{array}$ & $\begin{array}{c}16 \\
(26.67 \%)\end{array}$ & $\begin{array}{c}60 \\
(100 \%)\end{array}$ \\
\hline 6 & $\begin{array}{c}1 \\
(1.67 \%)\end{array}$ & $\begin{array}{c}3 \\
(5.00 \%) \\
\end{array}$ & $\begin{array}{c}10 \\
(16.67 \%) \\
\end{array}$ & $\begin{array}{c}32 \\
(53.33 \%) \\
\end{array}$ & $\begin{array}{c}14 \\
(23.33 \%) \\
\end{array}$ & $\begin{array}{c}60 \\
(100 \%) \\
\end{array}$ \\
\hline Rata-rata & $3.06 \%$ & $7.50 \%$ & $13.89 \%$ & $52.50 \%$ & $23.06 \%$ & $100 \%$ \\
\hline
\end{tabular}

Sumber : Data Diolah 2021 
Berdasarkan dari tanggapan responden mengenai Pelatihan, kebanyakan responden memberikan jawaban setuju dengan rata-rata $54.23 \%$. Hal ini dapat dilihat pada setiap indikator pertanyaan yang disajikan mengenai Pelatihan dengan jawaban responden sebagai berikut:

1) Pelatihan yang dilaksakan, harus sesuai dengan kebutuhan instansi dan tujuan dari pelatihan itu. Kebanyakan responden menjawab setuju sebanyak 33 orang dengan persentase $55.00 \%$. Untuk jawaban sangat setuju sebanyak 13 orang dengan persentase $21.67 \%$. Untuk jawaban normal sebanyak 8 orang dengan persentase $13.33 \%$. Untuk jawaban tidak setuju sebanyak 4 orang dengan persentase $6.67 \%$. Untuk jawaban sangat tidak setuju sebanyak 2 orang dengan persentase $3.33 \%$.

2) Peserta pelatihan yang di terima harus memenuhi spesifikasi sebagai persyaratan peserta tanpa terkecuali. Kebanyakan responden menjawab setuju sebanyak 31 orang dengan persentase $51.67 \%$. Untuk jawaban sangat setuju sebanyak 13 orang dengan persentase $21.67 \%$. Untuk jawaban normal sebanyak 7 orang dengan persentase $11.67 \%$. Untuk jawaban tidak setuju sebanyak 6 orang dengan persentase $6.67 \%$. Untuk jawaban sangat tidak setuju sebanyak 3 orang dengan persentase $5.00 \%$.

3) Pelatih (trainer) dalam pelatihan perlu memiliki kompetensi yang sesuai dengan materi yang akan di bawakan untuk peserta. Kebanyakan responden menjawab setuju sebanyak 32 orang dengan persentase $53.33 \%$. Untuk jawaban sangat setuju sebanyak 15 orang dengan persentase $25.00 \%$. Untuk jawaban normal sebanyak 6 orang dengan persentase $10.00 \%$. Untuk jawaban tidak setuju sebanyak 5 orang dengan persentase $8.33 \%$. Untuk jawaban sangat tidak setuju sebanyak 2 orang dengan persentase $3.33 \%$.

4) Spesifikasi instruktur dalam pelatihan harus di tentukan, untuk menjaga arah dan tujuan kegiatan. Kebanyakan responden menjawab setuju sebanyak 33 orang dengan persentase $55.00 \%$. Untuk jawaban sangat setuju sebanyak 12 orang dengan persentase $20.00 \%$. Untuk jawaban normal sebanyak 9 orang dengan persentase $15.00 \%$. Untuk jawaban tidak setuju sebanyak 5 orang dengan persentase $8.33 \%$. Untuk jawaban sangat tidak setuju sebanyak 1 orang dengan persentase $1.67 \%$.

5) Dalam pelaksanaan pelatihan, waktu yang digunakan harus sesuai dengan kebutuhan program pelatihan tersebut. Kebanyakan responden menjawab setuju sebanyak 28 orang dengan persentase $46.67 \%$. Untuk jawaban sangat setuju sebanyak 16 orang dengan persentase $26.67 \%$. Untuk jawaban normal sebanyak 10 orang dengan persentase $16.67 \%$. Untuk jawaban tidak setuju sebanyak 4 orang dengan persentase $6.67 \%$. Untuk jawaban sangat tidak setuju sebanyak 2 orang dengan persentase $3.33 \%$.

6) Pengaturan schedule harus diperhatikan, agar dapat terjadi ketepatan waktu pelaksanaan pelatihan. Kebanyakan responden menjawab setuju sebanyak 32 orang dengan persentase $53.33 \%$. Untuk jawaban sangat setuju sebanyak 14 orang dengan persentase $23.33 \%$. Untuk jawaban normal sebanyak 10 orang dengan persentase $16.67 \%$. Untuk jawaban tidak setuju sebanyak 3 orang dengan persentase $5.00 \%$. Untuk jawaban sangat tidak setuju sebanyak 1 orang dengan persentase $1.67 \%$.

\section{b) Variabel Kompetensi}

Kompetensi merupakan cerminan dari keterampilan dan pengetahuan seseorang atau dapat pula dikatakan sebagai karakteristik yang mendasari seseorang dan berkaitan dengan efektivitas kinerja individu dalam pekerjaannya. Kompetensi juga dapat dikatakan yaitu merupakan karakteristik dasar dari seseorang yang memungkinkan memberikan kinerja ungguk dalam perkjaan, peran atau situasi tertentu. Kompetensi mencakup melakukan sesuatu, tidak hanya pengetahuan pasif. Sebagai contoh yaitu seseorang pegawai mungkin pandai, akan tetapi jika pegawai itu tidak menterjemahkan kepandaiannya ke dalam perilaku di tempat kerja yang efektif, maka kepandaian pegawai itu tidak akan berguna.

Deskripsi terhadap variable kompetensi dilakukan dari hasil jawaban responden mengenai pertanyaan indikator-indikator kompetensi dengan nilai sebagai berikut:

Tabel 5. Tanggapan Responden atas Variabel Kompetensi

\begin{tabular}{|c|c|c|c|c|c|c|}
\hline \multirow{2}{*}{ Pertanyaan } & \multicolumn{5}{|c|}{ Jawaban } & \multirow{2}{*}{ Frekuensi } \\
\hline & STS (5) & TS (4) & $\mathrm{N}(3)$ & S (2) & SS (1) & \\
\hline 1 & $\begin{array}{c}1 \\
67 \%\end{array}$ & $\begin{array}{c}2 \\
33 \%\end{array}$ & 6 & $\begin{array}{c}39 \\
6500 \%\end{array}$ & 12 & 60 \\
\hline 2 & $\begin{array}{c}(1,0) \\
2 \\
(3.33 \%)\end{array}$ & $\begin{array}{c}3.5 \%) \\
3 \\
(5.00 \%)\end{array}$ & $\begin{array}{c}6 \\
6 \\
(10.00 \%)\end{array}$ & $\begin{array}{c}33 \\
(55.00 \%)\end{array}$ & $\begin{array}{c}16 \\
(26.67 \%)\end{array}$ & $\begin{array}{c}60 \\
(100 \%)\end{array}$ \\
\hline 3 & $\begin{array}{c}(3.55 \%) \\
1 \\
(1.67 \%)\end{array}$ & $\begin{array}{c}6 \\
(10.00 \%)\end{array}$ & $\begin{array}{c}8 \\
8\end{array}$ & $\begin{array}{c}31 \\
(51.67 \%)\end{array}$ & $\begin{array}{c}14 \\
(23.33 \%)\end{array}$ & $\begin{array}{c}60 \\
(100 \%)\end{array}$ \\
\hline 4 & $\begin{array}{c}1.0) \\
1 \\
(1.67 \%)\end{array}$ & $\begin{array}{c}3 \\
(5.00 \%)\end{array}$ & $\begin{array}{c}5 \\
(8.33 \%)\end{array}$ & $\begin{array}{c}37 \\
(61.67 \%)\end{array}$ & $\begin{array}{c}14 \\
(23.33 \%)\end{array}$ & $\begin{array}{c}60 \\
(100 \%)\end{array}$ \\
\hline 5 & $\begin{array}{c}2 \\
(3.33 \%)\end{array}$ & $\begin{array}{c}2 \\
2 \\
(3.33 \%)\end{array}$ & $\begin{array}{c}8 \\
(13.33 \%)\end{array}$ & $\begin{array}{c}30 \\
(50.00 \%)\end{array}$ & $\begin{array}{c}18 \\
(30.00 \%)\end{array}$ & $\begin{array}{c}60 \\
(100 \%)\end{array}$ \\
\hline 6 & $\begin{array}{c}2 \\
(3.33 \%)\end{array}$ & $\begin{array}{c}5 \\
(8.33 \%)\end{array}$ & $\begin{array}{c}7 \\
(11.67 \%)\end{array}$ & $\begin{array}{c}33 \\
(55.00 \%)\end{array}$ & $\begin{array}{c}13 \\
(21.67 \%)\end{array}$ & $\begin{array}{c}60 \\
(100 \%)\end{array}$ \\
\hline Rata-rata & 2.50 & 5.83 & 11.11 & 56.39 & 24.17 & $100 \%$ \\
\hline
\end{tabular}

Sumber : Data Diolah 2021

Berdasarkan dari tanggapan responden mengenai Kompetensi, kebanyakan responden memberikan jawaban setuju dengan rata-rata $56.39 \%$. Hal ini dapat dilihat pada setiap indikator pertanyaan yang disajikan mengenai Kompetensi dengan jawaban responden sebagai berikut:

1) Instruktur senantiasa berkompetensi secara konsisten menimbulkan tindakan dalam mendorong atau mengarahkan perilaku terhadap tujuan yang ada pada instansi. Kebanyakan responden menjawab setuju sebanyak 39 orang dengan persentase $65.00 \%$. Untuk jawaban sangat setuju sebanyak 12 orang dengan persentase $20.00 \%$. Untuk jawaban normal sebanyak 6 orang dengan persentase $10.00 \%$. Untuk jawaban tidak setuju sebanyak 2 
orang dengan persentase $3.33 \%$. Untuk jawaban sangat tidak setuju sebanyak 1 orang dengan persentase $1.67 \%$.

2) Karakter fisik instruktur senantiasa konsisten terhadap situasi ataupun informasi yang sedang berkembang. Kebanyakan responden menjawab setuju sebanyak 33 orang dengan persentase $55.00 \%$. Untuk jawaban sangat setuju sebanyak 16 orang dengan persentase $26.67 \%$. Untuk jawaban normal sebanyak 6 orang dengan persentase $10.00 \%$. Untuk jawaban tidak setuju sebanyak 3 orang dengan persentase $5.00 \%$. Untuk jawaban sangat tidak setuju sebanyak 2 orang dengan persentase $3.33 \%$.

3) Sikap dan Nilai nilai yang dimiliki menjadi sesuatu yang dijunjung tinggi terhadap sesuatu yang ideal, dicita citakan yang diwujudkan dalam pekerjaan dan kehidupan. Kebanyakan responden menjawab setuju sebanyak 31 orang dengan persentase $51.67 \%$. Untuk jawaban sangat setuju sebanyak 14 orang dengan persentase $23.33 \%$. Untuk jawaban normal sebanyak 8 orang dengan persentase $13.33 \%$. Untuk jawaban tidak setuju sebanyak 6 orang dengan persentase $10.00 \%$. Untuk jawaban sangat tidak setuju sebanyak 1 orang dengan persentase $1.67 \%$.

4) Pengetahuan, pengalaman, serta intuisi sebagai kemampuan penting dalam menyelesaikan tugas tertentu yang diperoleh pada proses belajar mampu meningkatkan efisiensi instansi . Kebanyakan responden menjawab setuju sebanyak 37 orang dengan persentase $61.67 \%$. Untuk jawaban sangat setuju sebanyak 14 orang dengan persentase $23.33 \%$. Untuk jawaban normal sebanyak 5 orang dengan persentase $8.33 \%$. Untuk jawaban tidak setuju sebanyak 3 orang dengan persentase $5.00 \%$. Untuk jawaban sangat tidak setuju sebanyak 1 orang dengan persentase $1.67 \%$.

5) Kompetensi Instruktur, mampu memproses pengetahuan atau data dalam meneentukan sebab dan berpengaruh dalam mengorganisasi rencana. Kebanyakan responden menjawab setuju sebanyak 30 orang dengan persentase $50.00 \%$. Untuk jawaban sangat setuju sebanyak 18 orang dengan persentase $30.00 \%$. Untuk jawaban normal sebanyak 8 orang dengan persentase $13.33 \%$. Untuk jawaban tidak setuju sebanyak 3 orang dengan persentase $3.33 \%$. Untuk jawaban sangat tidak setuju sebanyak 2 orang dengan persentase $3.33 \%$.

6) Kompetensi harus sesuai dengan maksud dan tujuan Instansi. Kebanyakan responden menjawab setuju sebanyak 33 orang dengan persentase $55.00 \%$. Untuk jawaban sangat setuju sebanyak 13 orang dengan persentase $21.67 \%$. Untuk jawaban normal sebanyak 7 orang dengan persentase $11.67 \%$. Untuk jawaban tidak setuju sebanyak 5 orang dengan persentase $8.33 \%$. Untuk jawaban sangat tidak setuju sebanyak 2 orang dengan persentase $3.33 \%$.

\section{c) Variabel Kinerja}

Kinerja merupakan hasil yang diperoleh oleh pegawai atas pekerjaan yang didibebankan kepadanya. Setiap instasi pemerintahan tentunya dituntut meberikan kinerja yang baik sebagai kemajuan dari instansi tersebut. Penekanan kinerja yang baik tentunya memberi gambaran keberhasilan atas sistem dan kepemimpinan dalam sebuah instasi. Instansi pemerintahan sebagai pelayan masyarakat harus memberi rasa puas terhadap masyarakat, sehingga jelas bahwa kinerja harus didirong untuk lebih baik dari hasil yang diperoleh sebelumnya.

Deskripsi mengenai variabel kinerja akan diuraikan berdasarkan jawaban responden yang disajikan sebagai berikut:

Tabel 6. Tanggapan Responden atas Variabel Kinerja

\begin{tabular}{|c|c|c|c|c|c|c|}
\hline \multirow{2}{*}{ Pertanyaan } & \multicolumn{5}{|c|}{ Jawaban } & \multirow{2}{*}{ Jumlah } \\
\hline & STS (5) & TS (4) & $\mathrm{N}(3)$ & $\mathrm{S}(2)$ & SS (1) & \\
\hline & 1 & 4 & 12 & 29 & 14 & 60 \\
\hline 1 & $(1.67 \%)$ & $(6.67 \%)$ & $(20.00 \%)$ & $(48.33 \%)$ & $(23.33 \%)$ & $(100 \%)$ \\
\hline 2 & $\begin{array}{c}2 \\
(3.33 \%)\end{array}$ & $\begin{array}{c}4 \\
(6.67 \%)\end{array}$ & $\begin{array}{c}12 \\
(20.00 \%)\end{array}$ & $\begin{array}{c}29 \\
(48.33 \%)\end{array}$ & $\begin{array}{c}13 \\
(21.67 \%)\end{array}$ & $\begin{array}{c}60 \\
(100 \%)\end{array}$ \\
\hline 3 & $\begin{array}{c}2 \\
(3.33 \%)\end{array}$ & $\begin{array}{c}4 \\
(6.67 \%)\end{array}$ & $\begin{array}{c}10 \\
(16.67 \%)\end{array}$ & $\begin{array}{c}32 \\
(53.33 \%)\end{array}$ & $\begin{array}{c}12 \\
(20.00 \%)\end{array}$ & $\begin{array}{c}60 \\
(100 \%)\end{array}$ \\
\hline 4 & $\begin{array}{c}1 \\
(1.67 \%)\end{array}$ & $\begin{array}{c}4 \\
(6.67 \%)\end{array}$ & $\begin{array}{c}11 \\
(18.33 \%)\end{array}$ & $\begin{array}{c}34 \\
(56.67 \%)\end{array}$ & $\begin{array}{c}10 \\
(16.67 \%)\end{array}$ & $\begin{array}{c}60 \\
(100 \%)\end{array}$ \\
\hline 5 & $\begin{array}{c}1 \\
(1.67 \%)\end{array}$ & $\begin{array}{c}5 \\
(8.33)\end{array}$ & $\begin{array}{c}8 \\
\text { (13.33\%) }\end{array}$ & $\begin{array}{c}33 \\
(55.00 \%)\end{array}$ & $\begin{array}{c}13 \\
(21.67 \%)\end{array}$ & $\begin{array}{c}60 \\
(100 \%)\end{array}$ \\
\hline 6 & $\begin{array}{c}3 \\
(5.00 \%)\end{array}$ & $\begin{array}{c}5 \\
(8.33 \%)\end{array}$ & $\begin{array}{c}8 \\
(13.33 \%)\end{array}$ & $\begin{array}{c}36 \\
(60.00 \%)\end{array}$ & $\begin{array}{c}8 \\
(13.33 \%)\end{array}$ & $\begin{array}{c}60 \\
(100 \%)\end{array}$ \\
\hline Rata-rata & $2.78 \%$ & $7.22 \%$ & $16.94 \%$ & $53.61 \%$ & $19.45 \%$ & $100 \%$ \\
\hline
\end{tabular}

Sumber : Data Diolah 2021

Berdasarkan dari tanggapan responden mengenai Variabel Kinerja, kebanyakan responden memberikan jawaban setuju dengan rata-rata $53.61 \%$. Hal ini dapat dilihat pada setiap indikator pertanyaan yang disajikan mengenai Variabel Kinerja dengan jawaban responden sebagai berikut:

1) Setiap pegawai harus meningkatkan kualitas dalam melakukan pekerjaannya. Kebanyakan responden menjawab setuju sebanyak 29 orang dengan persentase $48.33 \%$. Untuk jawaban sangat setuju sebanyak 14 orang dengan persentase $23.33 \%$. Untuk jawaban normal sebanyak 12 orang dengan persentase $20.00 \%$. Untuk jawaban tidak setuju sebanyak 4 orang dengan persentase $6.67 \%$. Untuk jawaban sangat tidak setuju sebanyak 1 orang dengan persentase $1.67 \%$.

2) Pegawai yang telah mengikuti pelatihan lebih memahami pekerjaan yang diberikan untuk menimimalisir tingkat kesalahan dalam menyelesaikan pekerjaan yang diberikan. Kebanyakan responden menjawab setuju sebanyak 29 orang dengan persentase $48.33 \%$. Untuk jawaban sangat setuju sebanyak 13 orang dengan persentase $21.67 \%$. Untuk jawaban normal sebanyak 12 orang dengan persentase $20.00 \%$. Untuk jawaban tidak setuju sebanyak 4 orang dengan persentase $6.67 \%$. Untuk jawaban sangat tidak setuju sebanyak 2 orang dengan persentase $3.33 \%$. 
3) Peningkatan kuantitas pekerjaan menjadi keharusan yang harus dicapai oleh pegawai. Kebanyakan responden menjawab setuju sebanyak 32 orang dengan persentase $53.33 \%$. Untuk jawaban sangat setuju sebanyak 12 orang dengan persentase $20.00 \%$. Untuk jawaban normal sebanyak 10 orang dengan persentase $16.67 \%$. Untuk jawaban tidak setuju sebanyak 4 orang dengan persentase $6.67 \%$. Untuk jawaban sangat tidak setuju sebanyak 2 orang dengan persentase $3.33 \%$.

4) Pegawai yang telah mengikuti program pelatihan dapat menyelesaikan pekerjaan dengan baik, sehingga tidak terjadi penumpukan pekerjaan. Kebanyakan responden menjawab setuju sebanyak 34 orang dengan persentase $56.67 \%$. Untuk jawaban sangat setuju sebanyak 10 orang dengan persentase $16.67 \%$. Untuk jawaban normal sebanyak 11 orang dengan persentase $18.33 \%$. Untuk jawaban tidak setuju sebanyak 4 orang dengan persentase $6.67 \%$. Untuk jawaban sangat tidak setuju sebanyak 1 orang dengan persentase $1.67 \%$.

5) Absensi Pegawai menggambarkan kinerja yang baik. Kebanyakan responden menjawab setuju sebanyak 33 orang dengan persentase $55.00 \%$. Untuk jawaban sangat setuju sebanyak 13 orang dengan persentase $21.67 \%$. Untuk jawaban normal sebanyak 8 orang dengan persentase $13.33 \%$. Untuk jawaban tidak setuju sebanyak 5 orang dengan persentase $8.33 \%$. Untuk jawaban sangat tidak setuju sebanyak 1 orang dengan persentase $1.67 \%$.

Pegawai yang telah mengikuti program dapat menyelesaikan pekerjaan tepat waktu. Kebanyakan responden menjawab setuju sebanyak 36 orang dengan persentase $60.00 \%$. Untuk jawaban sangat setuju sebanyak 8 orang dengan persentase $13.33 \%$. Untuk jawaban normal sebanyak 8 orang dengan persentase 13.33\%. Untuk jawaban tidak setuju sebanyak 5 orang dengan persentase $8.33 \%$. Untuk jawaban sangat tidak setuju sebanyak 3 orang dengan persentase $5.00 \%$.

Dalam penelitian ini membahas tentang sejauh mana pengaruh pelatihan, kompetensi intruktur Terhadap Kinerja Pegawai Balai Latihan Kerja Kabupaten Pangkep. Jenis penelitian ini adalah asosiatif, dimana dalam penelitian ini mencoba untuk menerawang hubungan antara variabel independen terhadapa variabel dependen. Sesuai dengan rumusan masalah dan hipotesis dalam penelitian ini, melihat hubungan Pelatihan terhadap kinerja pegawai, hubungan kompetensi terhadapkinerja pegawai dan hubungan kedua variabel independen yaitu pelatihan, kompetensi intruktur terhadap kinerja pegawai.

Penelitian ini mengambil sampel sebagai responden sebanyak 60 orang untuk menjadi alat ukur dengan berbagai karakteristik. Berdasarkan karakteristik tingkatan umur diketahui jumlah responden yang memiliki tingkatan umur antara 31 sampai 40 tahun tahun sebanyak 27 orang dengan persentase $45.00 \%$. Usia yang dianggap produktif karena mampu menyerap dan menerima hal yang baru serta memiliki semangat yang tinggi. Selanjutnya pada karakteristik tingkat pendidikan, pada tingkat strata satu (S1) memiliki angka yang lebih banyak yaitu 21 orang dengan persentase $35.00 \%$. Tingakat pendidkan yang tinggi dianggap lebih produktif dalam melaksanakan dan memahami pekerjaannya. Karakteristik pada jenis kelamin jumlah laki-laki jauh lebih banyak yaitu sebesar 37 orang dengan persentase $61.66 \%$. Umumnya laki-laki lebih produktif dibandingkan perempuan. Hal ini dikarenakan faktor fisik laki-laki jauh lebih besar dari pada perempuan, terutama bidang pekerjaan yang lebih menguras tenaga.

Pada analisis masalah selanjutnya dalam penelitian ini, mencoba mengetahui seberapa pengaruh pelatihan, kompetensi intruktur pada variabel kinerja pegawai pada balai latihan kerja kabupaten pangkep. Untuk menguji penelitian tersebut dilakukan dengan menggunakan metode analisis regresi berganda, uji $\mathrm{F}$ atau uji simultan dan uji t atau uji parsial. Secara umum hasil penelitian ini memuaskan. Segala hipotesis yang digambarkan diterima berdasalkan analisis hasil jawaban responden pada Balai Latihan Kerja Kabupaten Pangkep.

\section{3) Pengaruh Pelatihan Terhadap Kinerja Pegawai}

Dari hasil analisis persamaan regresi maka diperoleh hasil bahwa pelatihan memiliki pengaruh secara positif dan signifikan terhadap kinerja pegawai pada Balai Latihan Kerja Kabupaten Pangkep. Hal ini dapat dilihat dari nilai koefisien pelatihan bertanda positif dengan derajat signifikan lebih kecil dari pada standar. Dapat dikatakan bahwa indikator Kebutuhan pelatihan, Sasaran pelatihan, Kurikulum pelatihan, Peserta pelatihan, dan Pelatih (trainer), mempengaruhi kinerja pegawai telah menjadi bukti empirik sebagai syarat peningkatkan kinerja pegawai.

Hasil ini menguatkan teori pelatihan adalah keseluruhan kegiatan untuk memberi, memperoleh, meningkatkan, serta mengembangkan kompetensi kerja, produktivitas, disiplin, sikap, dan etos kerja pada tingkat keterampilan dan keahlian tertentu, sesuai dengan jenjang dan kualifikasi jabatan atau pekerjaan (Undang-Undang Nomor 13 Tahun 2003 tentang Ketenagakerjaan). Dimana tujuan pelatihan adalah meningkatkan produktivitas dan memperbaiki kualitas yang tentunya menjadi salah satu tolak ukur dari kinerja pegawai. Penelitian ini juga menunjukan hasil pelatihan berpengaruh positif dan signifikan terhadap peningkatan kinerja pegawai pada Balai Latihan Kerja Kabupaten Pangkep. Sehingga hasil dari penelitian ini mendukung hasil penelitian yang dilakukan oleh I Wayan Sutya Edy Kumara dan I Wayan Mudiartha Utama.

\section{4) Pengaruh Kompetensi}

Dari hasil persamaan regresi, diketahui bahwa kompetensi memiliki pengaruh yang searah dengan 
kinerja pegawai. Hal ini terlihat dari hasil yang menunjukan angka dengan tanda positif dengan derajat signifikan yang lebih kecil dari pada nilai standar signifikan. Kompetensi sangat dibutuhkan untuk meningkatkan kinerja pegawai pada Balai Latihan Kerja Kabupaten Pangkep, terlebih lagi bahwa instansi pemerintahan ini laboratorium pelayan peningkatan kapasitas masyarakat yang dituntut memberikan pelayanan prima. Penilaian kompetensi dapat dilihat dari tanggapan responden sebagai indikatornya adalah motif, watak, konsep diri, pengetahuan, dan keterampilan.

Hasil ini menguatkan teori yang menyatakan bahwa kompetensi merupakan suatu hal yang berkaitan dengan kemampuan dan keterampilan individu untuk mencapai hasil yang diharapkan (International Organization for Standardization, 2012). Kompetensi bertujuan untuk meningkatkan kemampuan individu dalam pencapaian yang diharapkan, tentunya tidak terlepas dari kinerja pegawai. Hasil yang ditunjukan adalah Kompetensi berpengaruh terhadap kinerja. Artinya semakin baik kompetensi maka semakin meningkat kinerjanya. Kompetensi pegawai Dinas Perdagangan dan Perindustrian Kota Banjarmasin tergolong dalam katagori sangat baik, dilihat dari indikator pengetahuan, keterampilan, konsep diri, watak, dan motif. Demikian pula kinerja pegawai Dinas Perdagangan dan Perindustrian Kota Banjarmasin juga tergolong dalam katagori sangat baik, dilihat dari indikator kualitas hasil kerja, kuantitas hasil kerja, ketepatan waktu kerja, kehadiran dan kerja sama.

\section{5) Pengaruh Pelatihan dan Kompetensi Terhadap Kinerja Pegawai}

Pengeloaan data regresi berganda yang dilakukan dalam penelitian ini memberikan hasil bahwa pelatihan, kompetensi instruktur berpengaruh positif dan signifikan terhadap kinerja pegawai pada Balai Latihan Krja Kabupaten Pangkep. Hal ini dapat dilihat dari nilai probabilitas yang lebih kecil dari nilai standar. Nilai $F$ hitung yang lebih besar dari nilai $\mathrm{F}$ tabel menjadi tolak ukur hasil dari penelitian ini tentang pengaruh ketiga variabel independen terdahap variabel dependen. Maka dari itu untuk kinerja pegawai pada Balai Latihan Kerja Kabupaten Pangkep senantiasa melakukan langkahlangkah yang dianggap dapat menciptakan gaya kepemimpinan yang baik, motivasi serta kepuasan kerja yang sangat dibutuhkan oleh pegawai untuk meningkatkan kinerjanya.

Hasil yang ditunjukan secara simultan kompetensi, pelatihan dan budaya organisasi berpengaruh signifikan terhadap kinerja pegawai. Sehingga dapat dikatan bahwa jika variabel pelatihan dan kompetensi dihubungkan secara simultan atau bersama-sama akan mempengaruhi secara positif kinerja pegawai.

\section{KESIMPULAN DAN SARAN}

Hasil penelitian dapat disimpulkan sebagai berikut:

a. Pengaruh Pelatihan. Penilaian pelatihan dapat dilihat dari tanggapan responden sebagai indikatornya adalah kebutuhan pelatihan, sasaran pelatihan, kurikulum pelatihan, peserta pelatihan, pelatih (trainer). Kebutuhan akan pelatihan memberi dampak yang positif terhadap kinerja pegawai, karena secara psikologi manusia membutuhkan dorongan sebagai kekuatan dalam melakukan hal yang terbaik dalam hidupnya. Dorongan tersebut dapat berasal dari dalam diri seseorang maupun dari luaar seeorang, sehingga dalam pekerjaan juga pegawai membutuhkan pelatihan sebagai kekuatan atau semangat bekerja untuk mencapai hasil yang maksimal.

b. Pengaruh Kompetensi. Berdasarkan hasil yang ditunjukan melalui analisis persamaan regresi. Artinya bahwa makin besar kompetensi, maka makin besar pula peningkatan kinerja yang dapat terjadi. Dapat dikatakan bahwa perencanaan, mempengaruhi, berkomunikasi, interpersonal, berfikir, organisasi, SDM, kepemimpinan, pelayanan, bisnis, manajemen individu, dan teknis senatiasa mempengaruhi kinerja dari seorang pegawai.

c. Pegaruh Pelatihan, Kompetesi terhadap Kinerja Pegawai. Pengeloaan data regresi berganda yang dilakukan dalam penelitian ini memberikan hasil bahwa pelatihan, kompetensi berpengaruh positif dan signifikan terhadap kinerja pegawai pada Balai Latihan Kerja Kabupaten Pangkep. Hal ini dapat dilihat dari nilai probabilitas yang lebih kecil dari nilai standar. Nilai $F$ hitung yang lebih besar dari nilai $\mathrm{F}$ tabel menjadi tolak ukur hasil dari penelitian ini tentang pengaruh dua variabel independen terdahap variabel dependen. Maka dari itu untuk kinerja pegawai pada Balai Latihan Kerja Kabupaten Pangkep senantiasa melakukan langkahlangkah yang dianggap dapat menciptakan gaya kepemimpinan yang baik, pelatihan serta kompetensi yang baik sangat dibutuhkan oleh pegawai untuk meningkatkan kinerjanya

\section{DAFTAR PUSTAKA}

Biech, Elaine, (2014). Training For Dummies by Elain Biech. New York: Mc. Edisi Terjemahan, Jakarta: Erlangga.

Bouder et al, (2014). Human Resource Management for Public and Nonprofit Organizations. San Fransisco: Jossey Bass. Edisi Terjemahan, Jakarta: PT. Prehaltindo.

Nawawi, Hadari. (2016). Evaluasi dan Manajemen Kinerja di Lingkungan Perusahaan dan Industri. Yogyakarta: Gadjah Mada University Press. 
Nurhayati, Dina. (2015). Manajemen Sumber Daya Manusia: Dasar dan Kunci Keberhasilan. Jakarta: Haji Masagung.

Mennakertrans No. Per.06/MEN/III/2006 tanggal 15 maret 2006, secara operational administratif bertanggung jawab langsung kepada Dirjen Pembinaan Pelatihan dan Produktivitas dan secara operational teknis dibawah Direktorat Instruktur dan Tenaga Pelatihan (INTALA).

Pasolong, Harbani. (2015). Teori Administrasi Publik. Bandung: Alfabeta.

Tyson, Shaun. (2014). Essentials Of Human Resource Management. United Kingdom: Elsever Ltd. Edisi Terjemahan, Jakarta: Erlangga.

Sugiyono. (2016). Statistika Untuk Penelitian. Bandung: Alfabeta. 